\title{
ADMINISTRATIVE EXPENDITURES OF SOCIAL SECURITY FUNDS IN UKRAINE
}

\author{
Nataliia Ivanchuk', Yulia Kharchuk ${ }^{2}$ \\ National University of Ostroh Academy, Ukraine
}

\begin{abstract}
Along with the expenditures for social protection, social security funds finance administrative direction, which should correspond to the amount of functions performed by a particular fund. The purpose of the paper is to determine ways to reduce administrative expenditures of state social security funds in the conditions of reforming Ukrainian economy. For this purpose, the authors investigate distribution of the expenditures between social security funds, analyse dynamics and structure of assignments for fund administration, and suggest possible ways to rationalize maintenance cost for these institutions. Methodology. Administrative expenditures are an integral part of the cost of social security funds and include particular items of expenses in the budget of these institutions. Applying a systematic approach to calculating the administrative costs of social security funds of Ukraine the authors have taken into account the expenditures related to funding management, support for information systems, and organization of work with insured people. Results of the survey showed that in 2007-2016 Pension Fund of Ukraine incurred the largest part of social expenditures (more than 90\%) compared with other social insurance funds (less than 10\%). At the same time, the administrative expenses were divided approximately into two halves between Pension Fund and other social security funds. In 2015, the government launched a reform of social insurance funds that aimed to reduce funds to three institutions but a decrease in the total amount of administrative expenditures has not been achieved yet. In addition, Pension Fund of Ukraine was least burdened with administrative expenses, while other social security funds with a relatively small share of social expenditures were burdened with administrative expenditures much more. Practical implications. Research showed that nowadays the existence of several social security funds in Ukraine is economically inexpedient and it is essential to concentrate functions of social protection in one institution. In particular, it may be appropriate to keep Pension Fund, which should concentrate all current social functions of social security funds naming it Single Social Fund of Ukraine. Value/originality. The assessment of administrative expenditures of social security funds in Ukraine is a systematic survey that allows making a comprehensive analysis of expenditures for the maintenance of mentioned institutions compared with the volume of functions assigned to these establishments.
\end{abstract}

Key words: social security funds, administrative expenditures, merger of social security funds, Pension Fund of Ukraine, Disability Insurance Fund of Ukraine, Unemployment Insurance Fund of Ukraine, Accident Insurance Fund of Ukraine, Social Security Fund of Ukraine.

JEL Classification: H50, G23, J28, J65

\section{Introduction}

State social security funds are influential in ensuring social protection of the population in Ukraine. Under the conditions of modern economic reform, the financing of these institutions is an urgent issue. In general, the problem of the deficit is particularly relevant for Pension Fund, which increasingly burdens the State budget every year. In 2007, an excess of expenditures over own revenues of Pension Fund reached to 24.4 billion UAH, while in 2016 this figure increased to 141.7 billion UAH or more than five times. At the same time, in 2016, the deficit exceeded the amount of fund's own income and was almost completely covered by the State budget financing.

Along with the expenditures for social functions, social security funds spend a certain amount of money on administrative direction, which should be expedient. Administrative expenditures should correspond to the amount of functions performed by a particular fund.

Scientists have repeatedly investigated the issue of reforming social insurance funds in Ukraine. Results of recent studies in the context of administration

Corresponding author:

${ }^{1}$ Department of Finance, Accounting and Audit, National University of Ostroh Academy.

E-mail: natalia.ivanchuk@oa.edu.ua

${ }^{2}$ Department of Finance, Accounting and Audit, National University of Ostroh Academy.

E-mail: julia.kharchuk@oa.edu.ua 
suggest to ensure the effectiveness of management of social insurance funds (Kovalevych, 2015; Rozhko, 2013), to reduce the number of social insurance funds to two institutions - Pension Fund and Social Security Fund (Servatynska, 2016; Berezina, 2015), unify the structure and competence distribution of social security fund management (Koval, 2014). Scientists also have noted that established Social Insurance Fund does not function properly and the reform of the system of social insurance funds, which started in 2015, was not complete. (Ivashchenko \& Maziarchuk, 2017). This proves the urgency of solving problems in the management of social security funds to achieve optimization of maintenance cost for these institutions. In this case, it is necessary to carry out a systematic survey that allows a comprehensive analysis of expenditures for the maintenance of mentioned institutions compared with the volume of functions assigned to these establishments.

The purpose of the paper is to determine ways to reduce the administrative expenditures of state social security funds in the conditions of reforming Ukrainian economy. Therefore, it is necessary to perform such scientific tasks as investigating expenditures distribution between social security funds, analysing dynamics and structure of assignments for fund administration, and suggesting ways to rationalize the maintenance cost for these institutions.

\section{Survey methodology}

Administrative expenditures are an integral part of the cost of social security funds and include particular items of expenses in the budget of these institutions. Applying a systematic approach to calculating the administrative costs of social security funds of Ukraine, the authors have taken into account expenditures related to funding management, support for information systems, and organization of work with insured people, in particular:

1. for Pension Fund of Ukraine:

- charges for cash services and a cash payment of pensions and benefits;

- management of pension system;

- compulsory state social insurance certificates and pension cards;

- forms, registers for the appointment and payment of pensions;
- creation of programmatic and technical support for the information and analytical system of Pension Fund of Ukraine;

- creation and introduction of the automated system for the Accumulation Fund of compulsory state pension insurance;

- implementation of measures related to the targeted delivery of notifications about the simplified procedure for the provision of housing subsidies to families with pensioners;

2. for Disability Insurance Fund of Ukraine:

- organizational and management activity;

- duties of the insurer fulfilment;

3. for Unemployment Insurance Fund of Ukraine:

- banking services;

- support for the information-reference system of the unemployed;

- maintenance of the executive directorate, its jurisdictions, State Employment Service Training Institute and fund management;

- creation of conditions for the reception, provision of social services and development of the material base;

4. for Accident Insurance Fund of Ukraine:

- measures to coordinate work with insured people;

- performance of other work related to the coordination of insurance activity;

- ensuring the work of the administrative board and supervisory board of the fund;

- fund activity organization;

- expenses for money transfer;

- court costs and enforcement fee.

\section{Distribution of expenditures between funds}

Pension Fund of Ukraine was established in 1990, Accident Insurance Fund of Ukraine and Unemployment Insurance Fund of Ukraine were created in 2000, and Disability Insurance Fund of Ukraine began its activity in 2001.

In 2001-2010, economic entities paid four different types of social taxes from payroll, and each fund administered its social tax separately.

From January 1, 2011, these social taxes were consolidated into a single social contribution and Pension Fund of Ukraine started its administration. At the same time, the other three social funds continued to perform other functions remained. From October 1,

Table 1

Structure of expenditures of social security funds in Ukraine during 2007-2016

\begin{tabular}{|l|c|c|c|c|c|c|c|c|c|c|}
\hline \multicolumn{1}{|c|}{ Funds } & \multicolumn{9}{c|}{ Years } \\
\cline { 2 - 18 } & 2007 & 2008 & 2009 & 2010 & 2011 & 2012 & 2013 & 2014 & 2015 & 2016 \\
\hline $\begin{array}{l}\text { Share of Pension Fund } \\
\text { expenditures, \% }\end{array}$ & 89.4 & 90.6 & 90.7 & 90.9 & 91.2 & 91.3 & 90.6 & 91.2 & 92.4 & 91.8 \\
\hline $\begin{array}{l}\text { Share of other social funds } \\
\text { expenditures, \% }\end{array}$ & 10.6 & 9.4 & 9.3 & 9.1 & 8.8 & 8.7 & 9.4 & 8.8 & 7.6 & 8.2 \\
\hline
\end{tabular}

Source: the results were calculated on the basic of budget implementation reports of social security funds and of data from State Statistics Service of Ukraine 
2013, the administration of single social contribution joined Ministry of Income and Fees, and from May 21, 2014, State Fiscal Service of Ukraine started to administer the mentioned contribution.

During 2007-2016, total expenditures of social security funds increased from 111.8 billion UAH to 276.1 billion UAH (in 2.5 times) (Table 1 ).

As a social fund with the most difficult financial situation, Pension Fund of Ukraine made the largest share of expenditures, compared with other social insurance funds. In general structure of expenditures of social funds, the share of Pension Fund in 2007 reached $89.4 \%$, and in $2016-91.8 \%$. At the same time, the share of other funds decreased from 10.6 to $8.2 \%$.

In 2015, the government launched a reform of social insurance funds that aimed to reduce administrative expenses to 600 million UAH. In particular, Social Security Fund of Ukraine was created through the merger of Accident Insurance Fund of Ukraine and Disability Insurance Fund of Ukraine. However, today the activity of the newly established institution is still under construction.

\section{Administrative expenditures formation}

DuringobservableperiodinUnemploymentInsurance Fund of Ukraine, the main item of administrative expenditures was maintenance of the executive directorate, its jurisdictions, State Employment Service Training Institute and fund management (in 2007 the share of this item was $72 \%$, and in 2016 it reached $91.3 \%$ of the administrative expenses of the fund).

Accident Insurance Fund of Ukraine had a predominance of costs for fund activity organization (more than 90\%).
Disability Insurance Fund of Ukraine appropriated the largest share of administrative expenditures to the organizational and managerial direction (more than 90\%).

Pension Fund of Ukraine spent the greatest amount of money on the management of pension system and creation of programmatic and technical support for the information and analytical system (97.2\% in 2016 from the total value of fund administrative expenses).

The survey of social funds administrative expenditures dynamics showed that, in Ukraine, there was a tendency for their growth, in particular, in 2016 they increased by 2.1 billion UAH or $77.8 \%$ in comparison with 2007 and reached 4.8 billion UAH (Table 2 ).

As a criterion of administrative expenditures growth rate expediency, we have chosen the dynamics of real GDP. From provided data, it can be seen that the increase in administrative expenditures of social funds was often excessive because it outstripped the growth of real GDP. Thus, we can estimate the dynamics of these expenditures positively only in 2011 and during 2014-2015.

The structure of administrative expenditures of social security funds of Ukraine shows that the mentioned expenses were divided approximately into two halves between Pension Fund and other social security funds (Table 3).

In 2007, the share of administrative expenditures of Pension Fund amounted to 49.4\%, and in 2016 it reached $51.7 \%$, while the share of other three funds decreased from $50.6 \%$ to $48.3 \%$. This indicates a nonrational structure of administrative expenditures, because during 2007-2016 Pension Fund spent over $90 \%$ of the total expenditures of social security funds, while the other three funds financed less than $10 \%$.

Table 2

Dynamics of administrative expenditures of Ukrainian social security funds and GDP during 2007-2016

\begin{tabular}{|c|c|c|c|c|c|c|c|c|c|c|}
\hline \multirow{2}{*}{ Indicators } & \multicolumn{10}{|c|}{ Years } \\
\hline & 2007 & 2008 & 2009 & 2010 & 2011 & 2012 & 2013 & 2014 & 2015 & 2016 \\
\hline $\begin{array}{l}\text { Nominal administrative } \\
\text { expenditures of social funds, } \\
\text { billion UAH }\end{array}$ & 2.7 & 4.0 & 3.8 & 4.6 & 4.8 & 4.9 & 5.2 & 4.6 & 4.7 & 4.8 \\
\hline $\begin{array}{l}\text { Growth rate of real expenditures of } \\
\text { social funds, billion UAH }\end{array}$ & - & 141.0 & 108.8 & 119.9 & 103.9 & 107.9 & 109.9 & 79.6 & 85.3 & 121.1 \\
\hline Real GDP growth rate, $\%$ & - & 102.2 & 84.9 & 104.1 & 105.4 & 100.2 & 100 & 93.4 & 90.2 & 102.4 \\
\hline
\end{tabular}

Source: the results were calculated on the basic of budget implementation reports of social security funds and of data from State Statistics Service of Ukraine

Table 3

Structure of administrative expenditures of social security funds in Ukraine during 2007-2016

\begin{tabular}{|l|c|c|c|c|c|c|c|c|c|c|}
\hline \multicolumn{1}{|c|}{ Indicators } & \multicolumn{9}{c|}{ Years } \\
\cline { 2 - 11 } & 2007 & 2008 & 2009 & 2010 & 2011 & 2012 & 2013 & 2014 & 2015 & 2016 \\
\hline $\begin{array}{l}\text { Share of Pension Fund } \\
\text { administrative expenditures, \% }\end{array}$ & 49.4 & 49.3 & 51.7 & 47.1 & 46.9 & 50.4 & 49.6 & 50.1 & 51.3 & 51.7 \\
\hline $\begin{array}{l}\text { Share of other social funds } \\
\text { administrative expenditures, \% }\end{array}$ & 50.6 & 50.7 & 48.3 & 52.9 & 53.1 & 49.6 & 50.4 & 49.9 & 48.7 & 48.3 \\
\hline
\end{tabular}

Source: the results were calculated on the basic of budget implementation reports of social security funds 
Table 4

The share of administrative expenditures in expenses of social security funds in Ukraine during 2007-2016

\begin{tabular}{|c|c|c|c|c|c|c|c|c|c|c|}
\hline \multirow{2}{*}{ Indicators } & \multicolumn{10}{|c|}{ Years } \\
\hline & 2007 & 2008 & 2009 & 2010 & 2011 & 2012 & 2013 & 2014 & 2015 & 2016 \\
\hline $\begin{array}{l}\text { In expenses of Disability Insurance } \\
\text { Fund, \% }\end{array}$ & 5.0 & 6.3 & 5.5 & 5.1 & 5.6 & 5.4 & 5.7 & 5.2 & 7.1 & 6.5 \\
\hline $\begin{array}{l}\text { In expenses of Unemployment } \\
\text { Insurance Fund, \% }\end{array}$ & 23.2 & 25.0 & 17.2 & 24.1 & 20.1 & 19.9 & 19.0 & 19.8 & 17.5 & 16.4 \\
\hline $\begin{array}{l}\text { In expenses of Accident Insurance } \\
\text { Fund, \% }\end{array}$ & 9.6 & 10.6 & 9.8 & 8.6 & 10.4 & 8.7 & 7.3 & 6.5 & 6.2 & 6.6 \\
\hline In expenses of Pension Fund, \% & 1.9 & 1.9 & 1.9 & 1.8 & 1.6 & 1.6 & 1.6 & 1.4 & 1.4 & 2.3 \\
\hline
\end{tabular}

Source: the results were calculated on the basic of budget implementation reports of social security funds

At the same time, the administrative expenses of Pension Fund reached 50\% of all expenditures for the maintenance of social funds. This calls into question the expediency of several off-budget institutions that perform social protection functions in Ukraine.

In 2015, the merger of two institutions into Social Security Fund of Ukraine has been initiated and the intention was to reduce administrative expenditures by 600 million UAH. However, according to the statistics (Table 2), the decrease in the total amount of administrative expenditures has not been achieved yet and, on the contrary, they grew from 4.7 billion UAH to 4.8 billion UAH during 2015-2016.

If to consider the structure of administrative expenditures in detail, it should be noted that the largest share belonged to Unemployment Insurance Fund of Ukraine - approximately 30\%. The shares of Disability Insurance Fund of Ukraine and Accident Insurance Fund of Ukraine were within $10 \%$ in the structure of administrative expenditures.

If to analyse the burden of social security funds with their administrative expenditures, it can be seen that the largest share of these expenditures belonged to Unemployment Insurance Fund of Ukraine (Table 4).

At the same time, in 2015 the reform of social security funds aimed to merger Disability Insurance Fund of Ukraine and Accident Insurance Fund of Ukraine, which had much smaller shares of administrative expenditures in their expenses.

With the largest share of social spending, Pension Fund of Ukraine was least burdened with administrative costs, while the other three social funds were much more burdened by administrative expenditures financing a relatively small share of social protection.

\section{Conclusions}

Nowadays the existence of several social security funds in Ukraine is economically inexpedient and it is essential to concentrate functions of social protection in one institution.

Liquidation of all social funds is a difficult task because it requires including a large number of additional items in the expenditure of State Budget. That is why it may be appropriate to keep Pension Fund, which should concentrate all current social functions of social security funds naming it Single Social Fund of Ukraine. At the same time, it is necessary to ensure proper transfer of all payments into cashless forms through applying banking system. In addition, it may be essential to put the functions of abolished social funds on the administrative apparatus of Pension Fund because a significant part of its control function, related to administration of the single social contribution, was subsequently delegated to State Fiscal Service of Ukraine.

It is also advisable to entrust the management of Single Social Fund only to state representatives because the state provides a social function mainly through the system of social security.

At the same time, the Cabinet of Ministers of Ukraine should appoint the entire composition of administrative and supervisory boards of Single Social Fund after presenting it by the Minister of Social Policy. The Ministry of Social Policy of Ukraine should keep control over the fund activity. We suggest including single social contribution and other proceeds of social security funds in State Budget revenues as a tax source and also applying budget financing of Single Social Fund.

\section{References:}

Berezina, S. (2015). Suchasni tendentsii v reformuvanni systemy sotsialnoho strakhuvannia Ukrainy [Modern trends in reforming of social insurance in Ukraine]. Bulletin of Taras Shevchenko National University of Kyiv, Economics, issue 3(168), p. 25-31. (in Ukrainian)

Ivashchenko, A., Maziarchuk, V. (2017). Analiz stanu reformuvannia Fondiv sotsialnoho strakhuvannya v Ukraini [Analysis of social security funds reform in Ukraine]. Kyiv, Financial and Economic Analysis Office in the VRU, 20 p. (in Ukrainian)

Koval, O. P. (2014). Modernizaciya systemy sotsialnoho strakhuvannia v Ukraini [Modernization of the social security system in Ukraine]. Kyiv, the National Institute for Strategic Studies, 38 p. (in Ukrainian) 
Kovalevych, D. A. (2015). Reformuvannia systemy sotsialnoho strakhuvannia [Social security reform]. Cherkasy University Bulletin: Economics Sciences, vol. 58, issue 2, p. 146-152. (in Ukrainian)

Rozhko, O. (2013). Shliakhy reformuvannia pozabiudzhetnykh tsilovykh fondiv sotsialnoho pryznachennia $\mathrm{v}$ Ukraini [Ways of reformation of off-budget special purpose funds of social setting in Ukraine]. Bulletin of Taras Shevchenko National University of Kyiv, Economics, issue 144, p. 41-44. (in Ukrainian)

Servatynska, I. M. (2016). Finansove zabezpechennia funktsionuvannia derzhavnykh fondiv sotsialnoho strakhuvannya [Financial support for the functioning of state social insurance funds] (PhD Thesis), Cherkasy State Technological University. 